\title{
121. Note on the Occurrence of Miogypsinoides Yabe \& Hanzawa in Oligocene Deposits.
}

\author{
By TAN SIK HoK. \\ (Comm. by H. YABE, M.I.A., Nov. 12, 1943.)
}

According to Leupold and Van der Vlerk (1931) the subgenus Miogypsinoides Yabe \& Hanzawa made its first appearance at the end of the Tertiary stage $e_{3}$, while its extinction is recorded to have taken place at the end of the Tertiary stage $f_{2}$. In other words, these authors consider the subgenus to range from the Upper Aquitanian till Middle Miocene time approximately.

In foraminiferal areas outside the Indo-Pacific (e. g. Marokko and Mexico) the subgenus appears much earlier, viz. in Oligocene time. From the fact that in the East Indian Archipelago a species of Miogypsinoides has become known which, according to its phylomorphogenetic qualities, must be considered as very primitive, viz. Miogypsinoides ubaghasi Tan, the suggestion was made that in the East Indian Tertiaries the subgenus could have made its appearance much earlier than is supposed usually, viz. Oligocene (Tan, 1936 a).

Not long after the publication of Tan's paper 1936 a, it could be establishad that Miogypsinoides ubaghasi occurs in strata situated about $100 \mathrm{~m}$ above the beds containing reticulate Camerines, which latter beds were found not higher than about $230 \mathrm{~m}$ above the highest $D i s-$ cocyclina-bearing sediments in the relative geological section (Tan, $1936 \mathrm{~b}$ ). This fact confirms. Tan's conclusion (1936 a) in so far that Miogypsinoides must indeed have appeared much earlier than was supposed by Leupold and Van der Vlerk, viz. Oligocene or Lower Aquitanian, but the proof that this appearance took place in Oligocene time was not yet given.

During the exploration of the Tjimandiri coalfield in 1942 a sample was collected (loc. Tjìmandiri, $\mathrm{N}$ of the mouth of the Tjibeuleungbeung), which contains both Camerina fichteli d'Arch. and a Miogypsinoides sp., accompanied by isolepidine-nephrolepidine and eulepidine Lepidocyclines.

This assemblage means a direct demonstration that Miogypsinoides indeed made its appearance in Oligocene time (at least Tertiary d), being consequently in full accord with the results of the phylomorphogenetic research of larger Foraminifera, carried out in the Palaeontological Laboratory of our Geological Survey, Bandoeng.

The economic significance of above statements is the followings:

A foraminiferal assemblage in which Miogypsinoides are present has generally been placed in Tertiary e at earliest. It is obvious that, as the subgenus in question appears to be already represented in Oligocene deposits (at least Tertiary d), part of the so-called Tertiary e, Miogypsinoides-bearing beds may be Oligocene in reality. A revision according to this new result may turn into an extension of our know- 
ledge concerning the distribution of the Oligocene sediments, which knowledge will eventually be valuable for the finding of Eocene series which, as is known, may be oil-bearing in Borneo.

\section{Literature.}

1931. W. Leupold \& I. M. Van der Vlerk: “The Tertiary" Leidsche Geologische Mededeelingen 5.

1936 a. Tan Sin Hok: Zur Kenntnis der Miogypsinideen. Ing. Ned. Indie. IV.

1936 b. Tan Sin Hok: Over verschillende palaeontologische criteria voor de geleding van het Tertiair. Idem, p. 173-179. 